\title{
A Comparative Study Of Probioticated Kunun-Zaki By Probiotic Strains Of Pediococci spp. And Lactobacillus rhamnosus GG
}

\author{
Bukola Christianah Adebayo-Tayo*, Soore Daniel Ademuwagun, Solomon Omoniyi Alao
}

Department of Microbiology, University of Ibadan, Ibadan, Oyo State, Nigeria

\section{A R T I C L E I N F O}

Article history:

Received 19 February 2016

Accepted 18 November 2016

Available online, ISSN: 2148-127X

\section{Keywords:}

Lactic acid bacteria

Probiotication

Kunun-zaki

Viability

Probiotic

${ }^{*}$ Corresponding Author:

E-mail: : bukola.tayo@gmail.com

A B S T R A C T

Non-dairy probiotic functional foods are receiving considerable interest recently owing to
the inability to cause allergy in certain segments of the population. Studies on
probiotication were carried out to determine the suitability of kunun-zaki as food matrix
for production of probiotic beverage using single and mixed culture of Pediococcus
acidilactici KU7, Pediococcus pentosaceus CREC5 and Lactobacillus rhamnosus GG.
Probioticated and un-probioticated kunun-zaki samples were designated PKZ and UPKZ,
respectively. There was a significant difference in the viable count during storage. Viable
counts of the LAB strains decreased with increasing storage time with $P$. acidilactici
KU7 having the highest viability at the beginning and end of storage $(3.43 \pm 0.06$ and
$0.93 \pm 0.12 \times 10^{8}$ cfu/ml). There was a decrease in pH of the PKZ samples within the $1^{\text {st }}$
and $3^{\text {rd }}$ week with corresponding increase in lactic acid production $(71.16 \pm 0.01-$
$441.39 \pm 0.01)$. Marked increase in pH and a decline in lactic acid were observed at the
$4^{\text {th }}$ week of storage in all samples. Total soluble solids content of the beverage was
observed to decrease with increasing storage time ranging from $8.25 \pm 0.01-4.97 \pm 0.01$.
There was no significant difference in pH and total soluble solids of UPKZ and colour of
the PKZ and UPKZ samples during storage. All the PKZ samples were able to inhibit the
growth of selected pathogens with marked variability amongst the samples. The UPKZ
sample also showed slight inhibitory activity. The samples showed a decline in proximate
and mineral composition at the end of storage. Sensory evaluation showed the PKZ
samples were preferred over the UPKZ samples. This study shows that probioticated
kunun-zaki can serve as a suitable non-dairy alternative to dairy probiotic formulations
and would be of health benefits to potential consumers.

\section{Introduction}

Probiotic foods are products containing live microorganisms with healthy properties for consumers (Mahmoudi et al., 2012). The use of probiotic bacterial cultures stimulates the growth of preferred microorganisms, crowds out potentially harmful bacteria and reinforces the body's natural defense mechanisms (Anal et al., 2007). Probiotic bacteria are frequently used in the food industry due to their beneficial properties including reduction of irritable bowel syndrome symptoms immunomodulatory effects, and cholesterol reduction (FAO/WHO, 2006). Most probiotic functional foods available in the market today are of dairy origin. However, owing to ethnic and cultural values, prevalence of lactose intolerance, milk sensitivity and high cholesterol content associated with dairy products, there have been increasing interest in producing suitable matrices for the development of non-dairy probiotics. Consumption of healthier foods such as probiotic fruit, vegetable juices and cereal based beverages has been reported to serve as a good option (Céspedes et al., 2013).

In the recent years many non-dairy probiotics drinks products have been developed. Microorganisms has been incorporated into drinks, cereal-based products, breakfast cereals, baby food and food supplements in form of tablets, capsules and freeze-dried preparation (BerniCanani et al., 2007). Interestingly, fermented cereal-based foods have been reported to offer opportunities to include probiotic, prebiotic and fibers in diet of consumers (Martins et al., 2013). Plant-based diets are recommended because of the many benefits that they confer, including lower levels of saturated fat, cholesterol, and animal protein, while offering higher sources of protein, carbohydrates, vitamins, minerals, dietary fibers, antioxidant, carotenoid, and phytochemical intake (American Dietetic Association, 2003).

Kunun-zaki is one of the most highly consumed cereal-based non-alcoholic, non-carbonated beverages in Nigeria (Ayo et al., 2004). It is a fermented non-alcoholic cereal beverage whose popularity is due to its characteristic sweet-sour taste typical of lactic acid bacterial fermented foods of African origin (Efiuvwevwere and Akoma, 1995). Cereals used for kunun-zaki include: sorghum (Sorghum bicolor), millet (Pennisetum typhoideum), maize (Zea mays), rice (Oryza sativa), acha (Digitalis exilis) or wheat (Triticuma estivum) and other cereals could be used in non-composite 
proportions. Kunun-zaki is normally flavored with a combination of spices commonly called "'kayan-yaji", which includes ginger (Zingiber officinale), cloves (Eugenia aromatica), black pepper (Piper guinese) and cinnamon (Xylopia acthiopica) (Adebayo et al., 2010) together with saccharifying agents such as paste of sweet potato tubers, malted rice, malted sorghum, crude extract from dried Cadaba farinose stems are also added (Onuorah et al., 1987). Research has been done on production of kunun-zaki but research work has not been done on probioticated kunun-zaki so there is little or no information on it. This research aimed at production of probioticated kunun-zaki using probiotic strains, stored at $4^{\circ} \mathrm{C}$ for four weeks and to determine the physicochemical parameters and sensory evaluation of the stored samples.

\section{Materials and Methods}

\section{Collection of Sample}

Rumen samples were collected from the gastrointestinal tract of a freshly slaughtered cow at the University of Ibadan abattoir. Millet (Pennisetum typhoides), sorghum (Sorghum bicolor), wheat, sweet potato and spices (ginger, clove, black pepper and red pepper) were obtained from Bodija market in Ibadan, South-west Nigeria. Paddy rice (Oryza sativa Faro 44) was obtained from the Institute of Agricultural Research and Training (I.A.R \&T), Apata, Ibadan, Nigeria. Food grade sodium metabisulphite (E223) and maltodextrin were obtained from a retail market in Ojota, Lagos state.

\section{Collection of Pathogenic Microorganisms}

Six pathogens (Bacillus cereus, Staphylococcus aureus, Klebsiella pneumonia, Streptococcus pyogenes, Escherichia coli and Pseudomonas spp. were collected from the Department of Medical Microbiology, University College Hospital (UCH), Ibadan and The Federal Institute of Industrial Research Oshodi (FIIRO), Lagos State. The isolates were sub-cultured on Nutrient Agar plates and incubated for 24 hours at $35-37^{\circ} \mathrm{C}$. The colonies were picked and stored on slants until when needed.

Standardization of LAB for Inoculation into Kunun-zaki

The LAB strains were standardized by using 0.5 McFarland standards which was used as reference to adjust the turbidity of microbial suspensions. The microbial cells were centrifuged and washed twice in phosphate buffer saline and were compared with the control by measuring the absorbance with that of the standard $0.5 \mathrm{McF}$ arland gives approximate cell density of $1.5 \times 10^{8} \mathrm{cfu} / \mathrm{mL}$, having absorbance of 0.063 at wavelength of $600 \mathrm{~nm}$ (Andrews, 2001).

Preparation of Kunun-zaki (Controlled Fermentation)

Kunun-zaki was produced using the method described by Agarry et al. (2010). Cereal grains were used in composite form. Millet (1 kg), sorghum (500 gr) and wheat grains $(250 \mathrm{gr})$ were cleaned and steeped in water overnight to soften the seed. The soaked grains were washed with $1 \%$ sodium metabisulphite to remove unwanted microorganisms, wet milled along with added spices surface sterilized with $1 \%$ sodium metabisulphite. ginger (12 gr), cloves (8 gr) (black pepper (6 gr), and red pepper (4 gr). Sweet potatoes (60 gr) and malted rice (600 gr) was added into the slurry. The slurry was divided into three parts: two parts were mixed together with $2.5 \mathrm{~L}$ of boiled water, stirred to form a gel, and allowed to cool for $2 \mathrm{~h}$ with the addition of starter culture (Lactobacillus rhamnosus GG and Pediococcus acidilacticiKU7) and left to ferment for $12 \mathrm{hrs}$. It was then sieved with a muslin cloth and the filtrate (4 L) to produce kunun-zaki.

\section{Production of the Probioticated Kunun-zaki Samples}

Probiotication of the kunun-zaki substrate was done by inoculating $80 \mathrm{ml}$ of each pasteurized kunun-zaki sample with $1 \%(\mathrm{v} / \mathrm{v})$ of the probiotic LAB (0.5 Mc Farland standard containing $\left.1.5 \times 10^{8} \mathrm{cfu} / \mathrm{ml}\right)$. Isolate codes were used to mask the identity of the samples. The pasteurized kunun-zaki samples inoculated with the probiotic LAB ( $P$. acidilacticiKU7, L. rhamnosus GG, $P$. Pentosaceus CREC5 and a mixed culture of the three probiotic LAB strains) was labeled as: PKZKU7 (kununzaki sample inoculated with Pediococcus pentosaceus KU7), PKZCREC5 (kunun-zaki sample inoculated with P. Pentosaceus CREC5), PKZRHAM (kunun-zaki sample inoculated with L. Rhamnosus GG), PKZCONSOR (kunun-zaki sample inoculated with $P$. Acidilactici KU7, P. Pentosaceus CREC5 and L. rhamnosus GG) and UPKZ (Un-inoculated kunun-zaki samples control). The inoculated kunun-zaki: sample was incubated at $37^{\circ} \mathrm{C}$ for $72 \mathrm{hrs}$ and stored at $4^{\circ} \mathrm{C}$ for four weeks.

Physicochemical Analysis of the Probioticated Kunun-zaki

Analysis of lactic acid, $p H$ and colour: All the analysis was carried out weekly during four week period. The production of lactic acid was determined by titrating $5 \mathrm{~mL}$ of the homogenized sample against $0.1 \mathrm{~N} \mathrm{NaOH}$ using $1 \mathrm{~mL}$ of phenolphthalein indicator $(0.5 \%$ in $50 \%$ alcohol). The titratable acidity was calculated as lactic acid $(\%, v / v)$. Each milliliter of $0.1 \mathrm{~N} \mathrm{NaOH}$ is equivalent to $90.08 \mathrm{mg}$ of lactic acid (Fayemi and Ojokoh, 2014). The $\mathrm{pH}$ of the probioticated juice samples stored at $4{ }^{\circ} \mathrm{C}$ for 1- 4 weeks was determined using a $\mathrm{pH}$ meter (Jenway, Essex UK) model 3505 equipped with a glass electrode. Colour assessment of the probioticated juice sample stored at different time interval was done by using colour meter. Total Soluble Solids (TSS) was determined using a hand refractometer (Erma, Japan) in terms of ${ }^{\circ} \mathrm{Bx}\left({ }^{\circ}\right.$ Brix) (Maskan, 2006).

Determination of the Viability of the LAB Strain inside the Kunun-zaki Substrate

The survivability of the LAB strain in the kunun-zaki samples was determined using a standard microbiological method. Samples from the stored probioticated beverage were pour plating at weekly intervals on MRS agar. The inoculated plate was incubated at $37^{\circ} \mathrm{C}$ for $48 \mathrm{hrs}$. Viable counts were recorded and expressed as colony forming unit (CFU per $\mathrm{mL}$ ). 


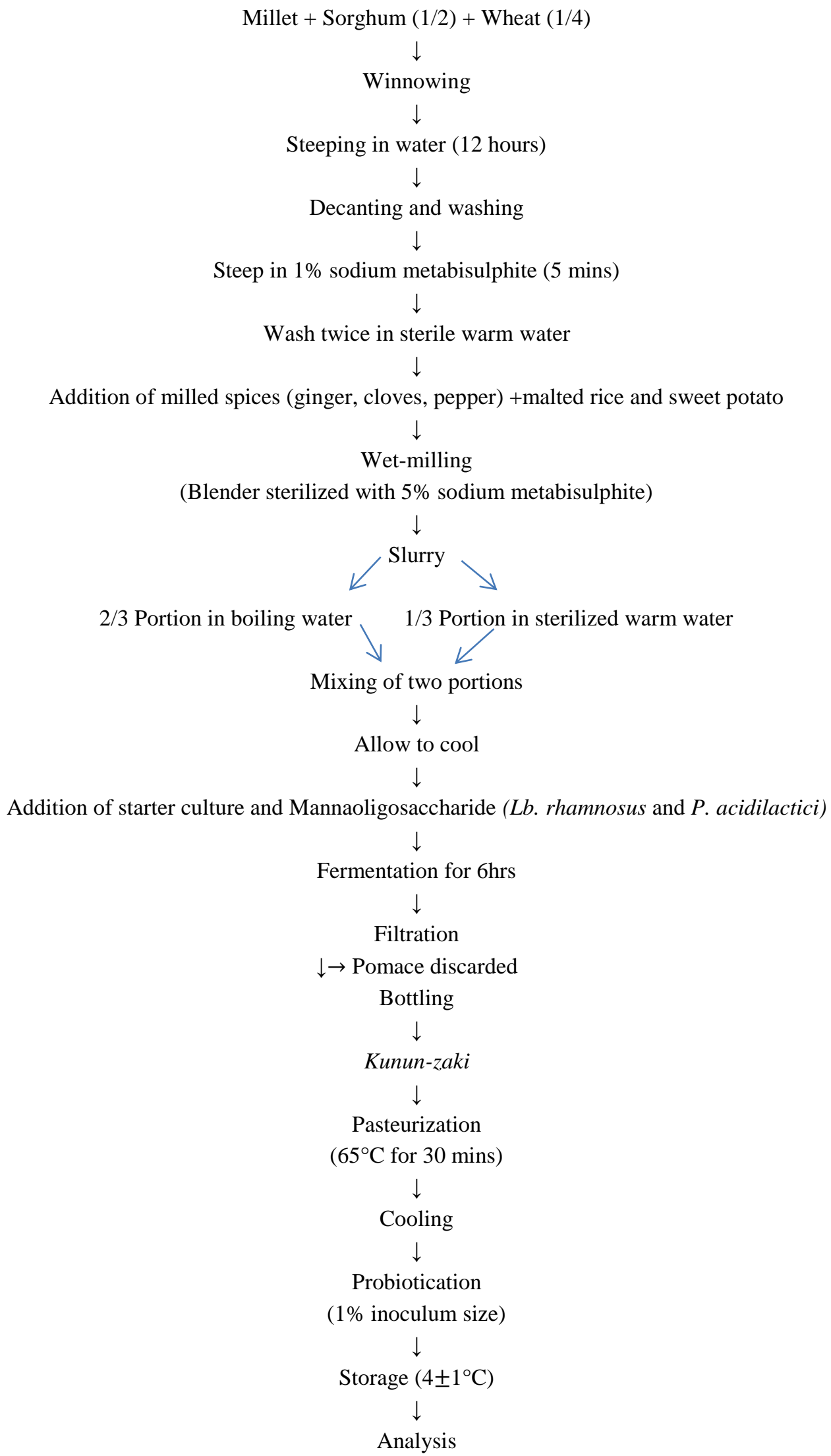

Mixing of two portions

$\downarrow$

Allow to cool

$\downarrow$

Addition of starter culture and Mannaoligosaccharide (Lb. rhamnosus and P. acidilactici) $\downarrow$

Fermentation for $6 \mathrm{hrs}$ $\downarrow$

Filtration

$\downarrow \rightarrow$ Pomace discarded Bottling

Kunun-zaki

$\downarrow$

Pasteurization

$\left(65^{\circ} \mathrm{C}\right.$ for $\left.30 \mathrm{mins}\right)$

$\downarrow$

Cooling

$\downarrow$

Probiotication

(1\% inoculum size)

$\downarrow$

Storage $\left(4 \pm 1^{\circ} \mathrm{C}\right)$

$\downarrow$

Analysis

Figure 1 Flow chart for production of probioticated kunun-zaki 
Determination of Antimicrobial Activity of the Stored Probioticated Kunun-zaki

Antimicrobial activity of the stored probioticated kunun-zaki was determined using the agar well diffusion method described by Toure et al. (2003). McFarland standard (0.5) of the indicator microorganisms was prepared. $18 \mathrm{hrs}$ old test organisms; E. coli, Bacillus cereus, S. aureus, Strep. pyogens, Kleb. pneumonia and Pse. spp. were swabbed on nutrient agar. Wells were bored on the agar with sterile $7 \mathrm{~mm}$ diameter cork borer. $1 \mathrm{ml}$ of the kunun-zaki samples were aseptically dispensed into the wells. Plates were then incubated aerobically at $30^{\circ} \mathrm{C}$ for $18 \mathrm{hrs}$. Diameter of zone of inhibition was measured.

Determination of Proximate and Mineral Composition of the Samples

The moisture content, crude protein, crude fiber, crude fat, ash content and carbohydrate of the kunun-zaki samples (dried matter basis) were determined in triplicates as described by AOAC (1990). Total carbohydrate content of the samples was calculated by difference method (subtracting the sum of percent moisture, crude protein, crude fibre, crude fat, and ash from $100 \%$ ).

The mineral contents were determined using Atomic Absorption Spectrophotometer (Buck 211VGP, by Buck Scientific, UK) Minerals such as Calcium (Ca), Magnesium (Mg), Iron (Fe), Copper $(\mathrm{Cu})$, and Zinc $(\mathrm{Zn})$ were determined using the method of AOAC (1990).

\section{Sensory Evaluation}

Sensory evaluation was carried out at the first and fourth week of the study. A total of 5 panellists who were familiar with kunun-zaki were selected within the Department of Microbiology and Food technology, University of Ibadan. Same-member panellist used at the first week was retained at the fourth week to ensure consistent taste profile amongst the tasters and possibly reduce bias. Member panellist aged between 24-28 years. Panellists were asked to rate each sample based on the characteristics of appearance, aroma, taste, colour, and overall acceptability using a seven-point hedonic scale ranging from $1=$ extremely like $-7=$ extremely dislike (Larmond, 1977).

\section{Statistical Analysis}

Data were subjected to analysis of variance (ANOVA) using Minitab 16.0 statistical software (Minitab Inc., State College, PA, USA) and they were characterized descriptively as means \pm standard deviation. Statistically significant means were separated using Duncan Multiple Range test (DMRT) and Fisher pairwise comparisons (FPC). The significance level adopted was $\mathrm{P} \geq 0.05$.

\section{Results and Discussion}

The suitability of food matrices of non-dairy origin as vehicle for survival of probiotic organisms has been a recent study approach. Study of the physicochemical properties of food product is important in determining optimum and sensitive ranges that is supportive to growth of probiotic. Hence, tests were carried out to determine the physicochemical parameters of the probioticated and control kunun-zaki samples throughout the study period.

$\mathrm{pH}$ values of the samples at different storage time was shown in Table 1. There were significant differences $(\mathrm{P} \geq 0.05)$ in values obtained across the weeks. $\mathrm{pH}$ of the PKZ samples was observed to be lower $(4.92-4$. 84) than the UPKZ sample $(4.95-4.92)$ within the $1^{\text {st }}$ and $3^{\text {rd }}$ week. At the $4^{\text {th }}$ week, $\mathrm{pH}$ value of the UPKZ samples (5.23) was observed to be higher than that of PKZ sample (5.19).

The $\mathrm{pH}$ range of the kunun-zaki samples was between 4.64 and 5.23. These values were consistent with the values obtained by Akoma et al. (2006) and Adejuyitan et al. (2008). The low $\mathrm{pH}$ values observed in all probioticated kunun-zaki samples could be due to the decomposition of fermentable substrates and sugars by the microorganisms which ferment carbohydrates to produce energy and principally lactic acid. This is in line with what was reported by Agarry et al. (2010).

No significant difference $(\mathrm{P} \geq 0.05)$ was detected in acidity of the UPKZ samples within the $2^{\text {nd }}$ and $4^{\text {th }}$ week. There were significant differences in the PKZ samples (Table 1). PKZACD produced the highest acidity $\left(441.39 \pm 0.01^{\mathrm{a}} \mathrm{g} / \mathrm{l}\right)$ while PKZCONSOR produced the lowest acidity at the $1^{\text {st }}$ week $\left(71.16 \pm 0.01^{\mathrm{c}} \mathrm{g} / \mathrm{l}\right)$.

Table 1 Physicochemical parameters of the probioticated and unprobioticated Kunun-zaki samples

\begin{tabular}{l|cccccc}
\hline \multirow{2}{*}{ Parameter } & ST & \multicolumn{5}{c}{ Samples } \\
\cline { 2 - 7 } & (week) & UPKZ & PKZPEN & PKZRHAM & PKZACD & PKZCONSOR \\
\hline \multirow{3}{*}{$\mathrm{pH}$} & 1 & $4.95 \pm 0.01^{\mathrm{a}}$ & $4.92 \pm 0.01^{\mathrm{b}}$ & $4.91 \pm 0.01^{\mathrm{b}}$ & $4.85 \pm 0.01^{\mathrm{d}}$ & $4.88 \pm 0.01^{\mathrm{c}}$ \\
& 2 & $4.94 \pm 0.01^{\mathrm{a}}$ & $4.89 \pm 0.01^{\mathrm{b}}$ & $4.84 \pm 0.00^{\mathrm{c}}$ & $4.71 \pm 0.01^{\mathrm{e}}$ & $4.83 \pm 0.01^{\mathrm{d}}$ \\
& 3 & $4.92 \pm 0.01^{\mathrm{a}}$ & $4.84 \pm 0.01^{\mathrm{b}}$ & $4.80 \pm 0.01^{\mathrm{c}}$ & $4.64 \pm 0.01^{\mathrm{e}}$ & $4.75 \pm 0.00^{\mathrm{d}}$ \\
& 4 & $5.23 \pm 0.01^{\mathrm{a}}$ & $5.18 \pm 0.00^{\mathrm{c}}$ & $5.19 \pm 0.01^{\mathrm{b}}$ & $5.14 \pm 0.01^{\mathrm{d}}$ & $5.18 \pm 0.01^{\mathrm{c}}$ \\
\hline \multirow{2}{*}{ Lactic acid } & 1 & $137.82 \pm 0.01^{\mathrm{b}}$ & $129.72 \pm 0.01^{\mathrm{c}}$ & $106.29 \pm 0.01^{\mathrm{d}}$ & $141.43 \pm 0.01^{\mathrm{a}}$ & $71.16 \pm 0.01^{\mathrm{e}}$ \\
(mg/l) $^{\mathrm{m}}$ & 2 & $176.56 \pm 0.00^{\mathrm{d}}$ & $176.56 \pm 0.03^{\mathrm{d}}$ & $247.72 \pm 0.01^{\mathrm{c}}$ & $309.88 \pm 0.01^{\mathrm{b}}$ & $374.73 \pm 0.04^{\mathrm{a}}$ \\
& 3 & $176.56 \pm 0.02^{\mathrm{d}}$ & $406.26 \pm 0.01^{\mathrm{b}}$ & $317.08 \pm 0.01^{\mathrm{c}}$ & $441.39 \pm 0.01^{\mathrm{a}}$ & $406.26 \pm 0.04^{\mathrm{b}}$ \\
& 4 & $176.56 \pm 0.01^{\mathrm{a}}$ & $123.41 \pm 0.01^{\mathrm{c}}$ & $123.41 \pm 0.00^{\mathrm{c}}$ & $176.56 \pm 0.01^{\mathrm{a}}$ & $375.63 \pm 0.01^{\mathrm{b}}$ \\
\hline
\end{tabular}

Means with the same alphabets within the same week down the column are not significantly different at P $\geq 0.05$, KEY: ST: Storage time (week), UPKZ: unprobioticated sample, PKZPEN: P. pentosaceusCREC5, PKZRHAM: L. rhamnosus GG, PKZACD: P. acidilactici KU7: PKZCONSOR: Consortium. 
Table 2 Physicochemical parameters of the probioticated kunun-zaki samples

\begin{tabular}{l|cccccc}
\hline \multirow{2}{*}{ Parameter } & \multirow{2}{*}{$\begin{array}{c}\text { ST } \\
\text { (week) }\end{array}$} & UPKZ & PKZPEN & PKZRHAM & PKZACD & PKZCONSOR \\
\cline { 2 - 7 } Total & 1 & $8.25 \pm 0.01^{\mathrm{a}}$ & $7.75 \pm 0.01^{\mathrm{b}}$ & $7.00 \pm 0.06^{\mathrm{cd}}$ & $7.23 \pm 0.40^{\mathrm{c}}$ & $6.75 \pm 0.13^{\mathrm{d}}$ \\
Soluble & 2 & $8.03 \pm 0.04^{\mathrm{a}}$ & $6.29 \pm 0.01^{\mathrm{b}}$ & $6.27 \pm 0.29^{\mathrm{b}}$ & $5.86 \pm 0.04^{\mathrm{c}}$ & $5.65 \pm 0.27^{\mathrm{c}}$ \\
Solid & 3 & $7.41 \pm 0.05^{\mathrm{a}}$ & $6.05 \pm 0.01^{\mathrm{c}}$ & $6.37 \pm 0.05^{\mathrm{b}}$ & $5.43 \pm 0.02^{\mathrm{d}}$ & $5.28 \pm 0.18^{\mathrm{d}}$ \\
( $^{\mathrm{o}}$ Brix) & 4 & $7.41 \pm 0.01^{\mathrm{a}}$ & $6.04 \pm 0.03^{\mathrm{c}}$ & $6.22 \pm 0.01^{\mathrm{b}}$ & $4.88 \pm 0.01^{\mathrm{e}}$ & $4.97 \pm 0.01^{\mathrm{d}}$ \\
\hline & 1 & $56.05 \pm 0.70^{\mathrm{c}}$ & $62.08 \pm 0.11^{\mathrm{b}}$ & $61.63 \pm 0.71^{\mathrm{b}}$ & $63.46 \pm 0.89^{\mathrm{a}}$ & $61.75 \pm 0.34^{\mathrm{b}}$ \\
Colour & 2 & $55.91 \pm 0.04^{\mathrm{e}}$ & $62.29 \pm 0.01^{\mathrm{b}}$ & $61.53 \pm 0.05^{\mathrm{d}}$ & $63.38 \pm 0.07^{\mathrm{a}}$ & $61.83 \pm 0.10^{\mathrm{c}}$ \\
& 3 & $55.85 \pm 0.05^{\mathrm{e}}$ & $62.2 \pm 0.020^{\mathrm{b}}$ & $61.38 \pm 0.01^{\mathrm{d}}$ & $63.24 \pm 0.24^{\mathrm{a}}$ & $61.63 \pm 0.04^{\mathrm{c}}$ \\
& 4 & $55.56 \pm 0.02^{\mathrm{d}}$ & $61.16 \pm 0.11^{\mathrm{b}}$ & $60.96 \pm 0.10^{\mathrm{c}}$ & $61.65 \pm 0.08^{\mathrm{a}}$ & $61.02 \pm 0.05^{\mathrm{bc}}$ \\
\hline
\end{tabular}

Means with the same alphabets within the same week down the column are not significantly different at P $\geq 0.05$, ST: Storage time (week),

The ability to produce high quantity of lactic acid is grossly dependent on the ability of the producer organisms to utilize carbon and nitrogen source of the medium as reported by Suma et al. (1999). The decrease in the acidity of all PKZ samples at the $4^{\text {th }}$ week could be due to the destruction of some of the microbial cells owing probably to competition amongst the LAB strains and nutrient depletion of the fermenting samples hence reducing the quantity of acid produced. This agrees with the work of Adeyemi and Umar (1994) who observed a decrease in the acidity of preserved kunun-zaki. Reddy et al. (1987) showed that the titratable acidity values were significantly influenced by the days of storage both at refrigeration and room temperature. The changes in $\mathrm{pH}$ and lactic acid observed in this study is in line with findings of Odunfa and Adeyele (1985): who reported these changes to be characteristic of the fermentation of carbohydrate rich plant material.

Results for Total Soluble Solids are shown in Table 2. The TSS of the UPKZ sample was observed to be higher than the probioticated samples throughout the study period. The values obtained from the UPKZ samples ranged from $8.25 \pm 0.01^{\mathrm{a}}-7.41 \pm 0.01^{\mathrm{a}}$ within the first and $4^{\text {th }}$ week. The PKZCONSOR samples which were observed to have the lowest TSS content had values ranged from $6.75 \pm 0.13^{\mathrm{d}}-4.97 \pm 0.01^{\mathrm{d}}$.

Change in colour of the samples during storage is shown in Table 2. Brightness was measured using a colour spectrophotometer in which values' tending towards 100 indicates increasing brightness. Brightness was observed to increase with increasing storage in all the samples. The UPKZ samples were observed to be the least bright with values of $56.05 \pm 0.70^{c}-55.56 \pm 0.02^{\mathrm{d}}$ within the $1^{\text {st }}$ and $4^{\text {th }}$ week respectively while PKZACD were the brightest with values ranging from $63.46 \pm 0.89^{\mathrm{a}}$ $-61.65 \pm 0.08^{\mathrm{a}}$ within the $1^{\text {st }}$ and $4^{\text {th }}$ week, respectively.
Total soluble solids obtained from the UPKZ samples at the $1^{\text {st }}$ and $4^{\text {th }}$ week $\left(8.25 \pm 0.01^{\mathrm{a}}\right.$ and $7.41 \pm 0.01^{\mathrm{a}}$ respectively) were higher and significantly different $(\mathrm{P} \geq 0.05)$ from the PKZ samples. The decrease in total solid content with increasing storage is consistent with the findings of Vijaya Kumar et al. (2015) who reported decrease in TSS of probioticated malted cereals (ragi, pearl millet and jowar) with $L$. casei. The decrease could be attributed to the corresponding increase in titratable acidity resulting from break down of sugars by surviving microorganisms to produce alcohol and gas. The result showed that high count of microorganisms could influence both TSS and lactic acid. TSS has been reported to impart sweet taste to the beverage. The colour reading of all samples revealed no significant difference $(\mathrm{P} \geq 0.05)$ between the colour parameters of the UPKZ. There was slight increase in the readings of the probioticated samples during storage (the closer the values are to 100 , the brightness of the samples which is indicative of fermentation). This is in agreement with the findings of Gardiner (2008) who reported that, in general, probiotic cultures do not tend to strongly modify the sensorial properties of the products to which they are added. The protein content $(1.27-1.34)$ of the PKZ samples was lower than the value $(7.57-15.43 \%)$ reported by Adejuyitan et al. (2008); and that from un-sieved kununzaki flour (3.63\%) reported by Amusa and Ashaye (2009) but was consistent with the value $(0.74 \%)$ obtained by Akoma et al. (2006).

Viability of the organisms in the kunun-zaki samples during the duration of storage is shown in Table 3 . Viability was observed to decrease with increasing storage in all PKZ samples. There were significant differences $(\mathrm{P} \geq 0.05)$ in viability in the PKZ samples. Total viable count ranged between 0.17-3.43 $\times 10^{8}$ cfu/mL. PKZKU7 had the highest viability, while PKZRHAM had the lowest viability.

Table 3 Viability $\left(\times 10^{8} \mathrm{cfu} / \mathrm{mL}\right)$ of the PKZ and the UPKZ samples

\begin{tabular}{l|cccc}
\hline \multirow{2}{*}{ Samples } & \multicolumn{4}{|c}{ Storage (week) } \\
\cline { 2 - 5 } & 1 & 2 & 3 & 4 \\
\hline UPKZCON & $0.00 \pm 0.00^{\mathrm{d}}$ & $0.00 \pm 0.00^{\mathrm{e}}$ & $0.00 \pm 0.00^{\mathrm{e}}$ & $0.00 \pm 0.00^{\mathrm{d}}$ \\
PKZPEN & $2.00 \pm 0.40^{\mathrm{b}}$ & $1.73 \pm 0.06^{\mathrm{b}}$ & $0.43 \pm 0.058^{\mathrm{d}}$ & $0.17 \pm 0.15^{\mathrm{d}}$ \\
PKZRHAM & $1.57 \pm 0.06^{\mathrm{c}}$ & $0.93 \pm 0.06^{\mathrm{c}}$ & $0.87 \pm 0.058^{\mathrm{b}}$ & $0.67 \pm 0.058^{\mathrm{b}}$ \\
PKZACD & $3.43 \pm 0.06^{\mathrm{a}}$ & $2.07 \pm 0.06^{\mathrm{a}}$ & $1.57 \pm 0.058^{\mathrm{a}}$ & $0.93 \pm 0.12^{\mathrm{a}}$ \\
PKZCONSOR & $3.17 \pm 0.06^{\mathrm{a}}$ & $0.57 \pm 0.06^{\mathrm{d}}$ & $0.63 \pm 0.115^{\mathrm{c}}$ & $0.47 \pm 0.058^{\mathrm{c}}$ \\
\hline
\end{tabular}


The viable count of the probiotic beverage did not fall below $10^{6} \mathrm{cfu} / \mathrm{mL}$ specified by FAO/WHO (2006). The viability of the isolates in the probioticated samples were significantly different $(\mathrm{P} \geq 0.05)$ when compared between storage time; with an observed decline with increasing storage. The result is in agreement with the report of Divya and Archana (2009); who reported a decline in total viable count of Lactobacillus reuteri and Bifidobacterium bifidum in whey based probiotic beverage stored at $4 \pm 1^{\circ} \mathrm{C}$. However, no viable bacteria were observed from the UPKZ sample.

Antimicrobial activity of the UPKZ and PKZ kununzaki samples is shown in Table 4. All probioticated samples produced moderate inhibition against selected clinical pathogens. Inhibitory zones ranged from 0.50 $12.7 \mathrm{~mm}$. PKZCREC5 produced the highest antimicrobial activity against $B$. cereus, while PKZKU7 produced its highest antimicrobial activity against $S$. aureus and $E$. coli. PKZRHAM produced its highest inhibition against E. coli. The PKZCONSOR produced the highest antimicrobial activity against $S$. aureus, $S$. pyogenes and $P$. sp. However, UPKZ sample displayed the lowest antimicrobial activity against all the indicator pathogens with inhibition zones between $0.00-0.33 \mathrm{~mm}$.

All PKZ samples produced moderate antimicrobial activity against the clinical pathogens used with zones ranging from $2.33 \pm 0.577-12.7 \pm 0.58 \mathrm{~mm}$ suggesting the potential beneficial effect for the gastrointestinal tract when administered as probiotics. PKZCREC5 was, however, unable to inhibit Pseudomonas spp. The minimal inhibition observed in the UPKZ $\left(0.33 \pm 0.58^{\mathrm{d}}\right)$, however, could be due to the spices used in the production of the beverage. This observation is consistent with the findings of Bankole et al. (1999) who reported the antimicrobial effect of spice in kunun-zaki production.

Proximate composition of the PKZ and UPKZ samples analyzed at different weeks $\left(1^{\text {st }}-4^{\text {th }}\right)$ of storage $\left(4 \pm 2{ }^{\circ} \mathrm{C}\right)$ is shown in Table 5. In addition, there was no significant difference $(\mathrm{P} \geq 0.05)$ in moisture content. Crude protein was observed to increase at the $4^{\text {th }}$ week while crude fat showed a decrease. PKZCREC5 showed significant differences $(\mathrm{P} \geq 0.05)$ in crude protein, crude fat, crude fibre, ash and carbohydrate. Increase in crude fibre was observed with decrease in crude fat, protein, ash and carbohydrate. PKZRHAM did not differ significantly in crude fibre content. There were significant differences $(\mathrm{P} \geq 0.05)$ in the other parameters. PKZKU7 showed significant differences $(\mathrm{P} \geq 0.05)$ in all parameters. Increase was observed in moisture, and crude fat, while crude protein, fibre, ash and carbohydrate showed decrease at the $4^{\text {th }}$ week. The highest moisture content in all probioticated samples was observed in PKZCONSOR; however there was significant difference $(\mathrm{P} \geq 0.05)$ in moisture content during storage. Moisture content, crude protein and carbohydrate decreased while crude fat and ash was observed to increase at the $4^{\text {th }}$ week. There was no significant difference $(\mathrm{P} \geq 0.05)$ in crude fibre of PKZCONSOR samples.

Table 4 Antagonistic activities of the PKZ and control samples against some pathogens

\begin{tabular}{l|ccccc}
\hline \multirow{2}{*}{\multicolumn{1}{c}{ Pathogens }} & \multicolumn{5}{c}{ Zone of inhibition $(\mathrm{mm})$} \\
\cline { 2 - 6 } & UPKC & PKCPEN & PKCRHAM & PKCACD & PKCCONSOR \\
\hline Bacillus cereus & $0.33 \pm 0.58^{\mathrm{d}}$ & $6.67 \pm 1.53^{\mathrm{a}}$ & $4.67 \pm 0.58^{\mathrm{bc}}$ & $3.67 \pm 0.58^{\mathrm{c}}$ & $5.67 \pm 0.58^{\mathrm{ab}}$ \\
S. aureus & $0.00 \pm 0.00^{\mathrm{d}}$ & $6.67 \pm 0.58^{\mathrm{c}}$ & $6.67 \pm 0.58^{\mathrm{c}}$ & $9.00 \pm 2.00^{\mathrm{b}}$ & $12.7 \pm 0.58^{\mathrm{a}}$ \\
Kleb. pneumoniae & $0.33 \pm 0.58^{\mathrm{d}}$ & $3.33 \pm 0.58^{\mathrm{bc}}$ & $4.33 \pm 0.58^{\mathrm{ab}}$ & $5.33 \pm 0.58^{\mathrm{a}}$ & $2.33 \pm 0.58^{\mathrm{c}}$ \\
Strep. pyogenes & $0.00 \pm 0.00^{\mathrm{c}}$ & $5.67 \pm 0.58^{\mathrm{b}}$ & $2.67 \pm 0.58^{\mathrm{bc}}$ & $5.00 \pm 2.00^{\mathrm{b}}$ & $9.00 \pm 3.00^{\mathrm{a}}$ \\
E. coli & $0.33 \pm 0.58^{\mathrm{b}}$ & $6.67 \pm 0.58^{\mathrm{a}}$ & $8.67 \pm 0.58^{\mathrm{a}}$ & $8.67 \pm 0.58^{\mathrm{a}}$ & $8.00 \pm 4.00^{\mathrm{a}}$ \\
Pseudomonos spp. & $0.33 \pm 0.58^{\mathrm{b}}$ & $0.50 \pm 0.71^{\mathrm{b}}$ & $3.00 \pm 2.00^{\mathrm{a}}$ & $3.33 \pm 0.58^{\mathrm{a}}$ & $5.00 \pm 2.00^{\mathrm{a}}$ \\
\hline
\end{tabular}

Table 5 Proximate analysis of the probioticated and control kunun-zaki samples at storage intervals

\begin{tabular}{c|lccccc}
\hline \multirow{2}{*}{$\begin{array}{c}\text { ST } \\
\text { (week) }\end{array}$} & \multicolumn{1}{|c}{ Parameters } & \multicolumn{5}{c}{ Samples } \\
\cline { 2 - 7 } & Moisture Content & $86.2 \pm 0.01^{\mathrm{c}}$ & $87.1 \pm 0.01^{\mathrm{b}}$ & $87.3 \pm 0.03^{\mathrm{b}}$ & $87.2 \pm 0.03^{\mathrm{b}}$ & $88.0 \pm 0.58^{\mathrm{a}}$ \\
& Crude Protein & $1.14 \pm 0.01^{\mathrm{d}}$ & $1.29 \pm 0.01^{\mathrm{bc}}$ & $1.31 \pm 0.01^{\mathrm{ab}}$ & $1.34 \pm 0.03^{\mathrm{a}}$ & $1.27 \pm 0.04^{\mathrm{c}}$ \\
& Crude Fat $^{\mathrm{a}}$ & $0.14 \pm 0.00^{\mathrm{a}}$ & $0.17 \pm 0.02^{\mathrm{a}}$ & $0.22 \pm 0.06^{\mathrm{a}}$ & $0.18 \pm 0.01^{\mathrm{a}}$ & $0.21 \pm 0.10^{\mathrm{a}}$ \\
WEEK 1 & Crude Fibre & $0.13 \pm 0.01^{\mathrm{a}}$ & $0.09 \pm 0.01^{\mathrm{bc}}$ & $0.09 \pm 0.04^{\mathrm{b}}$ & $0.07 \pm 0.01^{\mathrm{bc}}$ & $0.05 \pm 0.02^{\mathrm{c}}$ \\
& Ash & $2.19 \pm 0.02^{\mathrm{a}}$ & $1.93 \pm 0.10^{\mathrm{bc}}$ & $2.0 \pm 0.01^{\mathrm{b}}$ & $1.92 \pm 0.05^{\mathrm{bc}}$ & $1.84 \pm 0.01^{\mathrm{c}}$ \\
& CHO & $12.06 \pm 0.01^{\mathrm{b}}$ & $12.16 \pm 0.01^{\mathrm{ab}}$ & $12.23 \pm 0.06^{\mathrm{ab}}$ & $12.22 \pm 0.21^{\mathrm{ab}}$ & $12.34 \pm 0.01^{\mathrm{a}}$ \\
& Moisture Content & $86.3 \pm 0.09^{\mathrm{c}}$ & $87.1 \pm 0.20^{\mathrm{b}}$ & $87.4 \pm 0.10^{\mathrm{a}}$ & $87.3 \pm 0.02^{\mathrm{ab}}$ & $87.3 \pm 0.01^{\mathrm{a}}$ \\
\hline & Crude Protein $^{\mathrm{a}}$ & $0.93 \pm 0.01^{\mathrm{ab}}$ & $1.17 \pm 0.02^{\mathrm{a}}$ & $1.19 \pm 0.02^{\mathrm{a}}$ & $0.52 \pm 0.58^{\mathrm{b}}$ & $1.12 \pm 0.04^{\mathrm{a}}$ \\
& Crude Fat $_{\text {WEEK 4 }}$ & $0.12 \pm 0.02^{\mathrm{c}}$ & $0.13 \pm 0.01^{\mathrm{c}}$ & $0.24 \pm 0.01^{\mathrm{ab}}$ & $0.21 \pm 0.02^{\mathrm{b}}$ & $0.30 \pm 0.09^{\mathrm{a}}$ \\
& Crude Fibre & $0.13 \pm 0.01^{\mathrm{a}}$ & $0.10 \pm 0.01^{\mathrm{b}}$ & $0.09 \pm 0.02^{\mathrm{b}}$ & $0.06 \pm 0.01^{\mathrm{c}}$ & $0.05 \pm 0.01^{\mathrm{c}}$ \\
& Ash & $2.13 \pm 0.03^{\mathrm{a}}$ & $1.71 \pm 0.02^{\mathrm{d}}$ & $1.74 \pm 0.01^{\mathrm{d}}$ & $1.79 \pm 0.02^{\mathrm{c}}$ & $1.88 \pm 0.01^{\mathrm{b}}$ \\
& CHO & $12.05 \pm 0.01^{\mathrm{b}}$ & $12.03 \pm 0.02^{\mathrm{bc}}$ & $12.14 \pm 0.01^{\mathrm{a}}$ & $12.01 \pm 0.01^{\mathrm{bc}}$ & $11.96 \pm 0.09^{\mathrm{c}}$ \\
\hline
\end{tabular}

ST: Storage time (week), Means with the same alphabets within the same week down the column are not significantly different at $\mathrm{P} \geq 0.05$ 
Table 6 Mineral analysis of the probioticated and control kunun-zaki samples at storage intervals

\begin{tabular}{c|cccccc}
\hline \multirow{2}{*}{$\begin{array}{c}\text { ST } \\
\text { (week) }\end{array}$} & $\begin{array}{c}\text { Mineral element } \\
(\mathrm{mg} / 100)\end{array}$ & UPKZ & PKZ CREC5 & PKZ:RHAM & PKZ: KU7 & PKZ:CONSOR \\
\cline { 2 - 7 } & $\mathrm{Ca}^{++}$ & $0.81 \pm 0.03^{\mathrm{a}}$ & $0.66 \pm 0.01^{\mathrm{b}}$ & $0.55 \pm 0.13^{\mathrm{b}}$ & $0.87 \pm 0.01^{\mathrm{a}}$ & $0.43 \pm 0.01^{\mathrm{c}}$ \\
& $\mathrm{Mg}^{++}$ & $41.1 \pm 10.43^{\mathrm{a}}$ & $28.14 \pm 0.01^{\mathrm{b}}$ & $27.4 \pm 1.35^{\mathrm{b}}$ & $29.46 \pm 0.01^{\mathrm{b}}$ & $41.06 \pm 0.01^{\mathrm{a}}$ \\
WEEK 1 & $\mathrm{Fe}^{++}$ & $4.46 \pm 0.01^{\mathrm{b}}$ & $4.62 \pm 0.05^{\mathrm{a}}$ & $2.57 \pm 0.01^{\mathrm{c}}$ & $2.22 \pm 0.01^{\mathrm{d}}$ & $2.5 \pm 0.09^{\mathrm{c}}$ \\
& $\mathrm{Cu}^{++}$ & $0.022 \pm 0.004^{\mathrm{c}}$ & $0.026 \pm 0.001^{\mathrm{c}}$ & $0.036 \pm 0.002^{\mathrm{a}}$ & $0.032 \pm 0.002^{\mathrm{ab}}$ & $0.031 \pm 0.00^{\mathrm{b}}$ \\
& $\mathrm{Zn}^{++}$ & $1.25 \pm 0.09^{\mathrm{a}}$ & $0.48 \pm 0.01^{\mathrm{c}}$ & $0.51 \pm 0.01^{\mathrm{c}}$ & $0.90 \pm 0.01^{\mathrm{b}}$ & $0.25 \pm 0.02^{\mathrm{d}}$ \\
\hline & $\mathrm{Ca}^{++}$ & $0.76 \pm 0.01^{\mathrm{b}}$ & $0.72 \pm 0.01^{\mathrm{c}}$ & $0.65 \pm 0.01^{\mathrm{d}}$ & $0.91 \pm 0.02^{\mathrm{a}}$ & $0.56 \pm 0.01^{\mathrm{e}}$ \\
& $\mathrm{Mg}^{++}$ & $35.08 \pm 0.05^{\mathrm{b}}$ & $28.12 \pm 0.01^{\mathrm{d}}$ & $27.35 \pm 0.06^{\mathrm{e}}$ & $29.27 \pm 0.02^{\mathrm{c}}$ & $39.76 \pm 0.01^{\mathrm{a}}$ \\
& $\mathrm{Fe}^{++}$ & $4.43 \pm 0.01^{\mathrm{b}}$ & $4.65 \pm 0.01^{\mathrm{a}}$ & $2.59 \pm 0.01^{\mathrm{c}}$ & $2.33 \pm 0.01^{\mathrm{e}}$ & $2.54 \pm 0.00^{\mathrm{d}}$ \\
& $\mathrm{Cu}^{++}$ & $0.018 \pm 0.001^{\mathrm{d}}$ & $0.022 \pm 0.001^{\mathrm{c}}$ & $0.031 \pm 0.001^{\mathrm{a}}$ & $0.028 \pm 0.001^{\mathrm{b}}$ & $0.029 \pm 0.002^{\mathrm{b}}$ \\
& $\mathrm{Zn}^{++}$ & $0.018 \pm 0.001^{\mathrm{d}}$ & $0.38 \pm 0.02^{\mathrm{d}}$ & $0.45 \pm 0.01^{\mathrm{c}}$ & $0.76 \pm 0.01^{\mathrm{b}}$ & $0.21 \pm 0.01^{\mathrm{e}}$ \\
\hline
\end{tabular}

ST: Storage time (week), Means with the same alphabets down the column are not significantly different at P $\geq 0.05$, PKZRHAM: Lactobacillus rhamnosus GG, PKZKU7: Pediococcus acidilactici KU7, PKZCONSOR: Consortium

Table 7 Sensory evaluation of the probioticated kunun-zaki samples at the $1^{\text {st }}$ and $4^{\text {th }}$ week of storage $\left(4^{\circ} \mathrm{C}\right)$

\begin{tabular}{|c|c|c|c|c|c|c|c|c|}
\hline \multirow{3}{*}{$\begin{array}{l}\text { Sample } \\
\text { Code }\end{array}$} & \multicolumn{8}{|c|}{ Sensory Parameters } \\
\hline & \multicolumn{2}{|c|}{ Appearance } & \multicolumn{2}{|c|}{ Aroma } & \multicolumn{2}{|c|}{ Taste } & \multicolumn{2}{|c|}{ Colour } \\
\hline & Wk1 & Wk4 & Wk1 & Wk4 & Wk1 & Wk4 & Wk1 & Wk4 \\
\hline UPKZ & $3.8 \pm 0.45^{\mathrm{a}}$ & $4.6 \pm 0.89^{\mathrm{a}}$ & $3.4 \pm 0.55^{\mathrm{a}}$ & $4.0 \pm 0.71^{\mathrm{a}}$ & $4.2 \pm 0.45^{\mathrm{a}}$ & $5.2 \pm 0.84^{\mathrm{a}}$ & $2.6 \pm 1.14^{\mathrm{ab}}$ & $3.4 \pm 0.55^{\mathrm{a}}$ \\
\hline PKZCREC5 & $2.8 \pm 0.45^{\mathrm{b}}$ & $2.0 \pm 0.71^{\mathrm{b}}$ & $2.0 \pm 0.71^{\mathrm{b}}$ & $2.8 \pm 1.30^{\mathrm{b}}$ & $2.2 \pm 0.45^{\mathrm{b}}$ & $3.4 \pm 0.89^{\mathrm{b}}$ & $3.4 \pm 0.55^{\mathrm{a}}$ & $3.0 \pm 1.00^{\mathrm{a}}$ \\
\hline PKZRHAM & $2.4 \pm 0.89^{\mathrm{bc}}$ & $2.8 \pm 0.84^{\mathrm{b}}$ & $1.6 \pm 0.55^{\mathrm{b}}$ & $3.0 \pm 0.71^{\mathrm{ab}}$ & $1.8 \pm 0.45^{\mathrm{b}}$ & $2.2 \pm 0.84^{\mathrm{c}}$ & $2.0 \pm 1.00^{\mathrm{b}}$ & $3.0 \pm 0.71^{\mathrm{a}}$ \\
\hline PKZKU7 & $2.4 \pm 0.89^{\mathrm{bc}}$ & $2.6 \pm 0.89^{\mathrm{b}}$ & $2.2 \pm 0.45^{\mathrm{b}}$ & $2.8 \pm 0.84^{\mathrm{b}}$ & $1.8 \pm 1.1^{\mathrm{b}}$ & $2.8 \pm 0.84^{\mathrm{bc}}$ & $2.2 \pm 0.84^{\mathrm{b}}$ & $3.0 \pm 0.71^{\mathrm{a}}$ \\
\hline PKZ CONSOR & $1.6 \pm 0.55^{\mathrm{c}}$ & $2.8 \pm 0.45^{\mathrm{b}}$ & $1.8 \pm 0.84^{\mathrm{b}}$ & $3.2 \pm 0.84^{\mathrm{ab}}$ & $1.6 \pm 0.55^{\mathrm{b}}$ & $2.6 \pm 0.89^{\mathrm{bc}}$ & $2.4 \pm 0.55^{\mathrm{ab}}$ & $3.4 \pm 1.14^{\mathrm{a}}$ \\
\hline
\end{tabular}

MMeans with the same alphabets within the same week across the row are not significantly different at P $\leq 0.05$, Extremely Like, 2 - Strongly Like, 3 - Moderately Like, 4 - Like, 5 - Dislike, 6 - Strongly Dislike, 7 - Extremely Dislike

Mineral composition of the PKZ and UPKZ samples analyzed at the $1^{\text {st }}$ and $4^{\text {th }}$ week of storage is shown in Table 6. There were significant differences $(\mathrm{P} \leq 0.05)$ in $\mathrm{Mg}, \mathrm{Ca}$ and $\mathrm{Fe}, \mathrm{Cu}$ and $\mathrm{Zn}$ level at storage intervals (Table 6). Mg concentration was observed to be the highest mineral contained in all kunun-zaki samples. The PKZCONSOR sample had the highest Mg concentration $(41.06 \pm 0.01)$ at the $1^{\text {st }}$ week of storage $(P \geq 0.05)$. Values obtained for calcium were relatively high with the highest value recorded from the PKZKU7 at the $1^{\text {st }}$ week of storage. PKZCREC5 was observed to yield the highest iron content $\left(4.65 \pm 0.01^{\mathrm{a}}\right)$. PKZ RHAM had the highest yield of copper $\left(0.036 \pm .002^{\mathrm{a}}\right)$. The UPKZ was observed to have the highest zinc content $\left(1.25 \pm 0.09^{\mathrm{a}}\right)$ at the $1^{\text {st }}$ week of storage $(\mathrm{P} \geq 0.05)$.

There were significant differences $(\mathrm{P} \geq 0.05)$ in sensory properties of the PKZ and UPKZ samples at the $1^{\text {st }}$ and $4^{\text {th }}$ week (Table 7). The UPKZ samples were least preferred to the probioticated samples $(\mathrm{P} \geq 0.05)$. At the $1^{\text {st }}$ week, the PKZCONSOR was mostly preferred in appearance; there was no significant difference $(\mathrm{P} \geq 0.05)$ in appearance of PKZCREC5, PKZRHAM, PKZKU7 and PKZCONSOR in the fourth week. There was no significant difference $(\mathrm{P} \geq 0.05)$ in aroma of all probioticated samples at the $1^{\text {st }}$ week; PKZHAM and PKZCONSOR samples were mostly preferred. There was however no significant difference $(\mathrm{P} \geq 0.05)$ in aroma of the probioticated samples at the $4^{\text {th }}$ week.

The result obtained for the moisture content of kununzaki fell within the range of $86.2 \pm 0.01-88.0 \pm 0.58 \%$ which was consistent with $85.42-86.62 \%$ reported by Adejuyitan et al. (2008) and $85.30-86.38 \%$ obtained by Amusa and Ashaye (2009). The difference in moisture content within the $1^{\text {st }}$ and $4^{\text {th }}$ week was not significant
$(\mathrm{P} \geq 0.05)$. This could be due to the relatively high level of moisture in the product. The crude fat content $(0.22 \%)$ obtained was similar to the value $(0.53 \%)$ reported by Akoma et al. (2006), but differed with the value (3.63\%) reported by Amusa and Ashaye (2009). Crude fat was observed to reduce within the $1^{\text {st }}$ and $3^{\text {rd }}$ week of storage in all samples. The crude fibre content reported by Adejuyitan et al. (2008) differed $(1.13-14.6 \%)$ with that obtained (0.13) in this study. This may be attributed to the metabolic demand of substrates by the probiotics LAB used in this study. The fibre content of the probioticated samples was lower than the control. This could be due to utilization of the fibre as source of prebiotics as reported by Lamsal and Faubion (2009). The ash content agreed with that reported by Adejuyitan et al. (2008). Ash content was also observed to decrease with increasing storage. The decrease in the ash content could be as a result of its usage as metabolic nutrients for the growth of the probiotics. The overall proximate analysis obtained by Sopade (1992) is similar to those obtained in this study, although being different composite and standardization. The result obtained revealed that magnesium has the highest concentration $(41.1 \%)$ followed by $\mathrm{Fe}(4.46 \%)$, $\mathrm{Zn}(1.25 \%), \mathrm{Ca}(0.81 \%)$ and $\mathrm{Cu}$ had the least $(0.022 \%)$. These values are similar to those obtained by Nkama et al. (2010). The quantities of the trace element (copper) were relatively small compared with its tolerant limit (Department of Health, 1991).

The aim of sensory evaluation was to specify the most acceptable kunun-zaki beverage. The scorings for the PKZ samples were preferentially appreciable than the UPKZ samples. The tasters showed preference of the samples at the first week than at the fourth week. 
However, the consortium was most preferred by the tasters.

In conclusion, none of the storage times presented count below the threshold required by $\mathrm{FAO} / \mathrm{WHO}$ (from

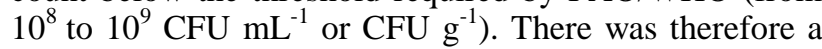
success in developing a formulation of probiotic kununzaki with single and mixed starters of Pediococcus spp. and L. rhamnosus GG stable in relation to physical and chemical characteristics of the product.

\section{References}

Adebayo GB, Otunola GA,Ajao TA.2010. Physicochemical, microbiological and sensory characteristics of kunu prepared from millet, maize and guinea corn and stored at selected temperatures. Adv. J.Fd Sci.Technol., 2(1): 41-46.

Adejuyitan JA, Adelakun OE, Olaniyan SA,Popoola FI. 2008. Evaluating the quality characteristics of kunu produced from dry-milled sorghum. Afr. J. Biotechnol., 7(13): 2244-2247.

Adeyemi IA,Umar, S. 1994. Effect of method of manufacture on quality characteristics of kununzaki, a millet based beverage. Nig. Fd. J., 12: 34-41.

Agarry OO, Nkama I, Akoma O. 2010.Production of Kunun-zaki (A Nigerian fermented cereal beverage) using starter culture. Int. Res. J. Microbiol., 1(2):18-25.

Akoma O, Jiya EA,Akumka DD,Mshelia E. 2006. Influence of malting on the nutritional characteristics of kunun-zaki. Afr. J. Biotechnol., 5(10): 996-1000.

Amusa NA, Ashaye OA. 2009. Effect of processing on nutritional, microbiological and sensory properties of kunu-zaki (a sorghum based non-alcoholic Beverage) Widely Consumed in Nigeria. Pak. J. Nut., 8(3): $288-292$.

Anal AK, Singh H. 2007. Recent advances in microencapsulation of probiotics for industrial applications and targeted delivery, Trends Fd. Sci. Technol., 18: 240-251.

Andrews JM. 2001. Determination of minimum inhibitoryconcentration. $J$. Antimicrob. Chemothera., 48:5-16.

AOAC 1990. Official Methods of Analysis (15th ed). Association of Official Analytical Chemists, Washington, D. C. pp.1113.

Ashiru AW, Olaleye OO, Egbenni PO. 2003. Occurrence of pathogenic organisms in kunun drink sold within Lagos metropolis, proceedings of the 27th Annual Nifst Conference. Pp 84.

Ayo JA, Umianze H, Gaffa T. 2004. Microbiological evaluation of "Kununzaki" and "Zoborodo" drink(beverage) locally produced and sold in a polytechnic community in Nigeria. Nig. Fd. J., 22: 119-126.

American Dietetic Association, Dietitians of Canada. 2003. Position of the American Dietetic Association and Dietitians of Canada: Vegetarian diets. J. Amer. Dietetic Assoc., 103(6): 748-65.

Bankole MO., Akpan I, Atanda, OO.1999. The antimicrobial effect of spices in "Kunu-tsamiya”. Nig. J.Microbiol., 13: 95-97.

Berni-canani R. 2007. Probiotics for treatment of acute diarrhea in children: randomized clinical trial of five different preparations. British Med. J., 335: 340-342.

Céspedes M, Cárdenas P, Staffolani M, Ciappini MC, Vinderola G. 2013. Performance in nondairy drinks of probiotic Lactobacilluscasei strains usually employed in dairy products. J. Fd. Sci.,78: M756-762.

Department of Health 1991. Dietary reference values for food and energy and nutrients for the UK. Report of the panel on dietary reference values of the committee on medical aspects of food policy. DH report on health and social subjects no. 41. London: HMSO.

Divya C, Archana K. 2009. Effect of different temperatures, timings and storage periods on physico-chemical and nutritional characteristics of whey guava beverage. World J. Dairy Fd. Sci., 4: 118-122.

EfiuvwevwereBO, Akoma AO. 1995. The microbiology of kununzaki, a cereal beverage from Northern Nigeria during the fermentation (production) process. World J. Microbiol. Biotechol., 11: 491-493.
FAO/WHO 2006. Food and Agriculture Organization of the United Nations, World Health Organization. Probiotics in food: health and nutritional properties and guidelines for evaluation. Rome: Food and Agriculture Organization of the United Nations: World Health Organization.

Fayemi OE, Ojokoh AO. 2014. The Effect of different fermentation techniques on the nutritional quality of the cassava product (fufu). J. Fd. Process. Preserv., 38:183-192.

Gacula JR. 1997. MC (ed.) Descriptive Sensory Analysis in Practice, Food and Nutrition Press. Connecticut, USA, 1:1-146.

Gardiner GE, O'Sullivan E, Kelly J, Auty MAE, Fitzgerald GF, Collins JK, Ross RP, Stanton, C. 2000. Comparative survival rates of human-derived probiotic Lactobacillus paracase $i$ and $L$. salivarius strains during heat treatment and spray drying. Appl. Env. Microbiol.,66 (6): 2605-2612.

Larmond E. 1977. Laboratory Methods for Sensory Evaluation of Food.Canada Department of Agriculture, Ottawa.

Lamsal BP, Faubion JM. 2009. The beneficial use of cereal components in probiotic foods. Fd. Rev. Int., 25(2): 103-114.

Mahmoudi R, Zare P, Hassanzadeh P,Nosratpour S.2012.Effect of Teucriumpolium Essential Oil on the Physicochemical and Sensory Properties of Probiotic Yoghurt. J. Fd. Process.Preserv., 38(3).

Martins EM, Ramos AM, Vanzela ES, Stringheta PC, Pinto CL, MartinsJM. 2013. Products of vegetable origin: A new alternative for the consumption of probiotic bacteria. Fd. Res. Int., 51: 764-770.

Maskan M. 2006. Production of pomegranate (Punicagranatum L.) juice concentrate by various heating methods: colour degradation and kinetics. J. Fd. Eng., 72: 218-224.

NkamaI, Agarry OO, Akoma O. 2010.Sensory and nutritional quality characteristics of powdered 'Kunun-zaki': A Nigerian fermented cereal beverage. Afr. J. Fd. Sci.,4(6):364 - 370.

Odunfa SA, Adeyele S. 1985. Microbiological changes during the traditional production of ogibaba a West African fermented Sorghum gruel. J. Cereal Sci., 3: 1723-1780.

Onuorah SI, Adesiyun AA, Adekeye, JO. 1987. Survival and multiplication of Staphylococcus aureus and Escherichia coli in Nigerian cereal drink (kununzaki). Effect of spices, $\mathrm{pH}$, and temperature. J. Fd. Agric., 1: 169-173.

Reddy GJ, Rao BVR, Reddy KRS, Venkayya D. 1987. Development of a Whey Beverage.Industr. J. Dairy Sci., 40: 445-450.

Sopade PA. 1992. Kununzaki and kunungyada - two Nigerian beverages. Fd Laboratory News, 8: 16-20.

Suma MV, Uma MS., Maheshwar MC, Karanth NG. 1999. Effect of nitrogen source on lactic acid production in abstracts of papers. International Workshop on Lactic Acid Bacteria. Central Food Technological Research Institute Mysore India, p. 18.

Toure R, Kheadr E, Moroni CL,FlissOI. 2003. Production of antibacterial substances by bifidobacterial isolates from infant stool active against Listeria monocytogenes. J. Appl. Microbiol., 95: 1058-1069.

Vijaya Kumar B, Naga SivuduS, Reddy OV. 2015.Studies on physico-chemical analysis of probioticated malted cereals with Lactobacillus casei and their possible applications. Int. J. Sci. Eng. Res., 6(2): 95-99.

American Dietetic Association, Dietitians of Canada. 2003. Position of the American Dietetic Association and Dietitians of Canada: Vegetarian diets. J. Amer. Dietetic Assoc, 103(6): 748-65.

EfiuvwevwereBO, Akoma AO. 1995. The microbiology of kununzaki, a cereal beverage from Northern Nigeria during the fermentation (production) process. World J. Microbiol. Biotechol., 11: 491-493.

Lamsal BP, Faubion JM. 2009. The beneficial use of cereal components in probiotic foods. Fd. Rev. Int.,25(2): 103-114.

Toure R, Kheadr E, Moroni CL, FlissOI. 2003. Production of antibacterial substances by bifidobacterial isolates from infant stool active against Listeria monocytogenes. J. Appl. Microbiol., 95: 1058-1069. 